\title{
Tebang Pilih Mengubah Keanekaragaman Semut Tanah Hutan di Kalimantan Timur, Indonesia
}

\section{(Selective Cutting Alters Diversity of Forest Ground Ants in East Kalimantan, Indonesia)}

\author{
Ahmad Budiaman $^{1 \star}$, Noor Farikhah Haneda ${ }^{2}$, Laela Nurahma ${ }^{1}$ \\ (Diterima Maret 2020/Disetujui Maret 2021)
}

\begin{abstract}
ABSTRAK
Penelitian ini menilai pengaruh jangka pendek tebang pilih pada keanekaragaman semut tanah (Hymenoptera: Formicidae) di hutan hujan sekunder. Semut tanah ditangkap menggunakan perangkap lubang (pitfall) di plot contoh berbentuk lingkaran seluas 0,5 ha. Sebanyak sembilan plot contoh diletakkan secara acak di salah satu petak tebangan seluas 98 ha. Lima belas perangkap lubang ditanam di setiap plot lingkaran. Keseluruhan perangkap lubang yang ditanam di petak tebang berjumlah 135. Rata-rata intensitas penebangan hutan adalah sebesar 8 pohon/ha. Pengambilan sampel serangga dan pengukuran faktor lingkungan dilakukan sebelum penebangan dan dua hari setelah penebangan. Dalam penelitian ini, kelimpahan, indeks keanekaragaman, indeks kekayaan jenis, dan indeks kemerataan jenis semut tanah sebelum penebangan dibandingkan dengan setelah penebangan. Hasil penelitian ini menunjukkan bahwa dampak jangka pendek tebang pilih pada semut tanah berbeda-beda. Tebang pilih dapat meningkatkan atau menurunkan kelimpahan dan komposisi morfospesies semut tanah. Kelompok semut tanah yang meningkat kelimpahannya sesudah tebang pilih adalah kelompok pemakan daun dan pemakan segala, sedangkan yang menurun kelimpahannya sesudah tebang pilih adalah kelompok pemangsa, pemakan bangkai, dan penyebar biji.
\end{abstract}

Kata kunci: ekosistem hutan, keanekaragaman hayati, pemanenan hutan, semut tanah hutan, tebang pilih

\section{ABSTRACT}

This study assesses the short-term effects of selective cutting on the diversity of ground ants (Hymenoptera: Formicidae) in the secondary rainforest. Ground ants were collected using a pitfall trap in a circular sample plot of 0.5 ha. A total of nine sample plots were randomly placed in a 98-ha cutting compartment. Fifteen pitfall traps were planted in each circular plot. A total of 135 pitfall traps were established in the cutting compartment. The average cutting intensity of 8 trees/ha was applied in the cutting compartment. Insect sampling and measurement of environmental factors were carried before cutting and two days after cutting. In this study, the abundance, diversity, species richness, and evenness index of ground ants before cutting compared to after cutting. The results of this study indicated that the short-term impact of selective cutting on ground ants was varied. Selective cutting may increase or decrease the abundance and morphospecies composition of ground ants. The abundance of forager and ground-dwelling omnivores increased after selective cutting, whereas for the predator, scavenger, and seed disperser ants were decreased after selective cutting.

Keywords: biodiversity, forest conservation, ground ant, selective cutting

\section{PENDAHULUAN}

Penebangan hutan merupakan salah satu gangguan hutan yang disebabkan oleh ulah manusia dan berkontribusi pada kehilangan biodiversitas dengan nilai konservasi dan fungsional tinggi (Hawthorne et al. 2011), dapat memengaruhi kekayaan jenis (Chaudary et al. 2016), dan sebagai penyebab utama gangguan keanekaragaman hayati di Asia Tenggara (Gibson et al. 2011; Woodcock et al. 2013; Burivalora et al. 2014).

1 Departemen Manajemen Hutan, Fakultas Kehutanan, Institut Pertanian Bogor, Kampus IPB Darmaga, Bogor 16680

2 Departemen Silvikultur, Fakultas Kehutanan, Institut Pertanian Bogor, Kampus IPB Darmaga, Bogor 16680

* Penulis Korespondensi: Email: budiaman@apps.ipb.ac.id
Hutan alam produksi di Indonesia, termasuk di Provinsi Kalimantan Timur, telah ditebang dengan sistem tebang pilih dan tanam Indonesia oleh hak pengusahaan hutan (HPH) sejak tahun 1970, tetapi peran $\mathrm{HPH}$ dalam menjaga hutan produksi alam sangat rendah (Gaveau et al. 2013). Kondisi ini dapat mengancam keseimbangan proses-proses dalam ekosistem hutan dan keanekaragaman hayati, termasuk keanekaragaman semut tanah.

Semut tanah merupakan salah satu jenis serangga, tergolong dalam Ordo Hymenoptera, Famili Formicidae. Semut tanah adalah kelompok avertebrata dominan di hutan tropis (Bihn et al. 2008; Griffiths et al. 2017), dan pemicu penting pada proses ekosistem, karena serangga ini dapat memengaruhi ketersediaan nutrisi bagi organisme lain yang hidup di lingkungan sekitarnya (Lavelle et al. 2006). Selain itu, spesies ini 
merupakan salah satu fauna tanah kecil yang berperan penting dalam mempertahankan kesuburan tanah, siklus hara, dan penyimpanan. Semut tanah dikenal sebagai organisme yang cepat merespons gangguan habitat, termasuk gangguan hutan akibat pemanenan hutan (Hoffman \& Andersen 2003). Berbagai penelitian sebelumnya menunjukkan bahwa kekayaan dan kemerataan jenis yang rendah merupakan ciri khas dari komunitas semut tanah pencari makan di hutan yang terganggu (Yeo et al. 2011, Latumahina et al. 2015). Hosoishi et al. (2017) menemukan bahwa tingkat gangguan hutan akibat penebangan hutan lebih berdampak pada semut tanah daripada semut pohon. Schreven (2013) melaporkan bahwa struktur komunitas semut di hutan rawa gambut dipengaruhi oleh tingkat gangguan hutan.

Dampak penebangan hutan pada serangga tanah telah banyak diteliti di hutan beriklim sedang (temperate), di antaranya terhadap Carabus olympiae (Negro et al. 2014), Coleoptera, Carabidae, dan Staphylinidae (Lange et al. 2014). Hanya sedikit penelitian yang mengkaji dampak pemanenan hutan alam tropis pada avertebrata di Asia Tenggara, khususnya pada serangga (Hawthorne et al. 2011). Penelitian dampak pemanenan hutan pada komunitas semut di hutan alam tropis sebagian besar dititikberatkan pada semut pohon (Hosoishi et al. 2017; Klimes 2017). Jumlah penelitian dampak penebangan hutan pada semut tanah di hutan alam tropis masih terbatas dan tidak umum (Mathieu et al. 2005). Oleh karena itu, penelitian ini bertujuan menganalisis (1) apakah kelimpahan dan kekayaan jenis semut tanah berbeda sebelum penebangan dan sesudah penebangan, dan (2) apakah kelimpahan dan kekayaan jenis hewan tersebut berkorelasi dengan perubahan faktor lingkungan akibat tebang pilih di hutan alam tropis tanah kering.

\section{METODE PENELITIAN}

Penelitian dilaksanakan pada salah satu petak tebang seluas 98 ha di suatu perusahaan konsesi hutan produksi alam di Kabupaten Mahulu, Kalimantan Timur, Indonesia, berlokasi pada koordinat $114^{\circ} 55^{\prime}-115^{\circ} 30^{\prime}$ BT dan $0^{\circ} 2^{\prime}$ LS $-0^{\circ} 15^{\prime}$ LU. Sistem silvikultur yang digunakan adalah sistem Tebang Pilih Tanam Indonesia (TPTI. Rata-rata curah hujan bulanan di hutan sekunder ini adalah $312 \mathrm{~mm}$ dan rata-rata suhu harian $31,6^{\circ} \mathrm{C}$. Penelitian lapangan dilakukan pada bulan Mei-Juni tahun 2016.

Sampel serangga dan faktor lingkungan diambil di dalam plot lingkaran berukuran $\pm 0,5$ ha sebelum dan sesudah penebangan. Jumlah plot lingkaran adalah 9 plot yang diletakkan secara acak di petak tebangan seluas 98 ha. Semua pohon jenis komersial berdiameter $>50 \mathrm{~cm}$ yang berada di dalam plot lingkaran ditebang menggunakan gergaji rantai oleh tim penebang perusahaan. Rata-rata jumlah pohon ditebang sebanyak 4 pohon/plot (8 pohon/ha). Sampel semut tanah diambil sebelum penebangan dan dua hari sesudah penebangan pohon menggunakan perangkap lubang (pitfall trap). Lima perangkap lubang diletakkan di subplot berbentuk bujur sangkar berukuran $1 \mathrm{~m} \times 1 \mathrm{~m}$. Satu perangkap dipasang di setiap siku dan satu dipasang di titik tengah subplot bujur sangkar. Subplot bujursangkar berjumlah tiga buah di setiap plot lingkaran, yang diletakkan pada jarak $20 \mathrm{~m}$ dari titik pusat plot lingkaran pada tiga arah mata angin, yaitu utara, barat laut, dan tenggara. Dengan demikian, semua perangkap yang dipasang berjumlah 135 buah. Data faktor lingkungan yang dikumpulkan adalah persen tutupan tajuk, tebal serasah, suhu, dan kelembapan udara. Data faktor lingkungan dikumpulkan sebelum penebangan dan sesudah penebangan pohon di subplot bujur sangkar. Semut tanah yang tertangkap diidentifikasi hingga tingkat morfospesies menggunakan kunci Bolton (1994) di Laboratorium Entomologi Hutan, Departemen Silvikultur, Fakultas Kehutanan, Institut Pertanian Bogor. Morfospesies adalah satu teknik identifikasi berdasarkan morfologi spesimen dan ini lazim digunakan sebagai pengganti keanekaragaman spesies (Strehlow et al. 2002; Abbott et al. 2002).

Keanekaragaman semut tanah dianalisis dengan menghitung indeks keanekaragaman jenis, indeks kekayaan jenis, dan indeks kemerataan jenis (Magguran 1988): $H^{\prime}=-\sum(P \ln P), P=n \cdot N^{-1}: D M g=(S-$ 1). $\left(\operatorname{In} M^{-1} ; E=H \text {. (In } S\right)^{-1}$; dengan $H^{\prime}=$ indeks keanekaragaman jenis Shannon-Wiener, $n=$ jumlah individu setiap jenis, $N=$ jumlah individu semua jenis, $D M g=$ indeks kekayaan jenis Margalef, dan $E=$ indeks kemerataan jenis. Uji $t$ berpasangan digunakan untuk menguji perbedaan kelimpahan dan komposisi morfospesies semut sebelum penebangan dan sesudah penebangan pada tingkat kepercayaan $95 \%$. Uji korelasi Pearson digunakan untuk menguji korelasi antara kelimpahan semut tanah dan perubahan faktor lingkungan akibat penebangan hutan.

\section{HASIL DAN PEMBAHASAN}

Kelimpahan semut tanah sebelum penebangan pohon sebanyak 1236 individu, yang terdiri atas empat subfamili dan 25 morfospesies. Setelah penebangan pohon, jumlah semut tanah yang tertangkap menurun menjadi 677 individu, yang terdiri atas atas empat subfamili dan 24 morfospesies. Subfamili semut tanah sebelum dan sesudah penebangan adalah Dolichoderinae, Formicinae, Myrmicinae, dan Ponerinae. Subfamili Ponerinae merupakan subfamili semut tanah yang terbanyak, diikuti oleh Myrmicinae, Formicinae, dan Dolichoderinae, baik sebelum penebangan maupun setelah penebangan pohon. Kelimpahan sebelum penebangan pohon lebih besar dibandingkan sesudah penebangan pohon (Gambar 1). Berdasarkan uji $t$ sampel berpasangan diperoleh bahwa kelimpahan semut tanah sebelum penebangan 
pohon berbeda nyata dengan kelimpahan sesudah penebangan pohon $(p<0,05)$ (Tabel 1$)$.

Terdapat tiga morfospesies semut tanah yang memiliki kelimpahan lebih tinggi dibandingkan morfospesies lainnya, baik sebelum penebangan maupun sesudah penebangan, yaitu berturut-turut Cryptopone sp., Odontoponera sp., dan Lophomyrmex sp.. Morfospesies semut yang meningkat kelimpahannya sesudah penebangan sebanyak enam morfospesies (Lophomyrmex sp., Oecophylla sp., Iridomyrmex sp., Monomorium sp., Calomyrmex sp. dan Recurvidris sp.), sedangkan yang menurun kelimpahannya sesudah penebangan sebanyak sembilan morfospesies (Cryptopone sp., Odontoponera sp., Diacamma sp., Mesostruma sp., Leptomyrmex sp., Vombisidris sp., Myopias sp., Euprenolepis sp. dan Paratrecina sp.). Tiga morfospesies semut (Camponotus sp., Dendromyrmex $\mathrm{sp}$. dan Lasiophanes sp.) tidak berubah kelimpahannya sesudah penebangan pohon (Tabel 2).

Semut tanah yang ditemukan di lokasi penelitian seluruhnya berjumlah 31 morfospesies. Dua puluh lima morfospesies ditemukan sebelum penebangan dan 24 morfospesies ditemukan sesudah penebangan. Terdapat tujuh morfospesies (Harpegnathos sp., Pheidologeton sp., Anochetus sp., Chimaeridris sp., Crematogaster sp., Prenolepis sp., Psalidomyrmex sp.) yang ditemukan hanya sebelum penebangan, dan lima morfospesies (Rhoptromyrmex sp., Lalomyrmex sp., Gnamptogenys sp., Heteroponera sp., Technomyrmex sp.) hanya ditemukan sesudah penebangan. Penebangan pohon dengan sistem tebang pilih di hutan alam produksi sekunder menyebabkan perubahan komposisi morfospesies semut tanah (Gambar 2). Berdasarkan uji $t$ sampel berpasangan terungkap bahwa komposisi morfospesies semut tanah sebelum penebangan pohon berbeda nyata dengan komposisi morfospesies sesudah penebangan pohon $(p<0,05)$ (Tabel 3$)$.

Indeks keanekaragaman, indeks kekayaan, dan indeks kemerataan jenis semut tanah berubah sesudah penebangan pohon dengan sistem tebang pilih di hutan produksi alam sekunder. Indeks keanekaragaman, indeks kekayaan, dan indeks kemerataan jenis menunjukkan kecenderungan menurun sesudah penebangan pohon. Berdasarkan hasil tersebut, tidak terdapat perbedaan yang nyata pada ketiga indeks tersebut sebelum penebangan dan sesudah penebangan (Gambar 3).

Hasil penelitian menunjukkan bahwa terdapat empat peranan fungsional serangga ini di lokasi penelitian, yaitu pemangsa (predator), pencari makan (foragers), pemakan bangkai (scavengers), dan penyebar biji (seed disperser). Semut yang terbanyak tertangkap sebelum penebangan hutan adalah pemangsa $(82,7 \%)$, diikuti oleh semut tanah pencari makan (14,3\%), pemakan bangkai $(2,51 \%)$, dan terakhir penyebar biji $(0,49 \%)$. Sementara sesudah penebangan, peringkat fungsional semut tanah di lokasi penelitian tidak berubah, pemangsa tetap menduduki urutan teratas, diikuti oleh pencari makan, pemakan bangkai, dan penyebar biji. Fakta tersebut menunjukkan bahwa presentase pemangsa, pemakan bangkai, dan penyebar biji berkurang sesudah

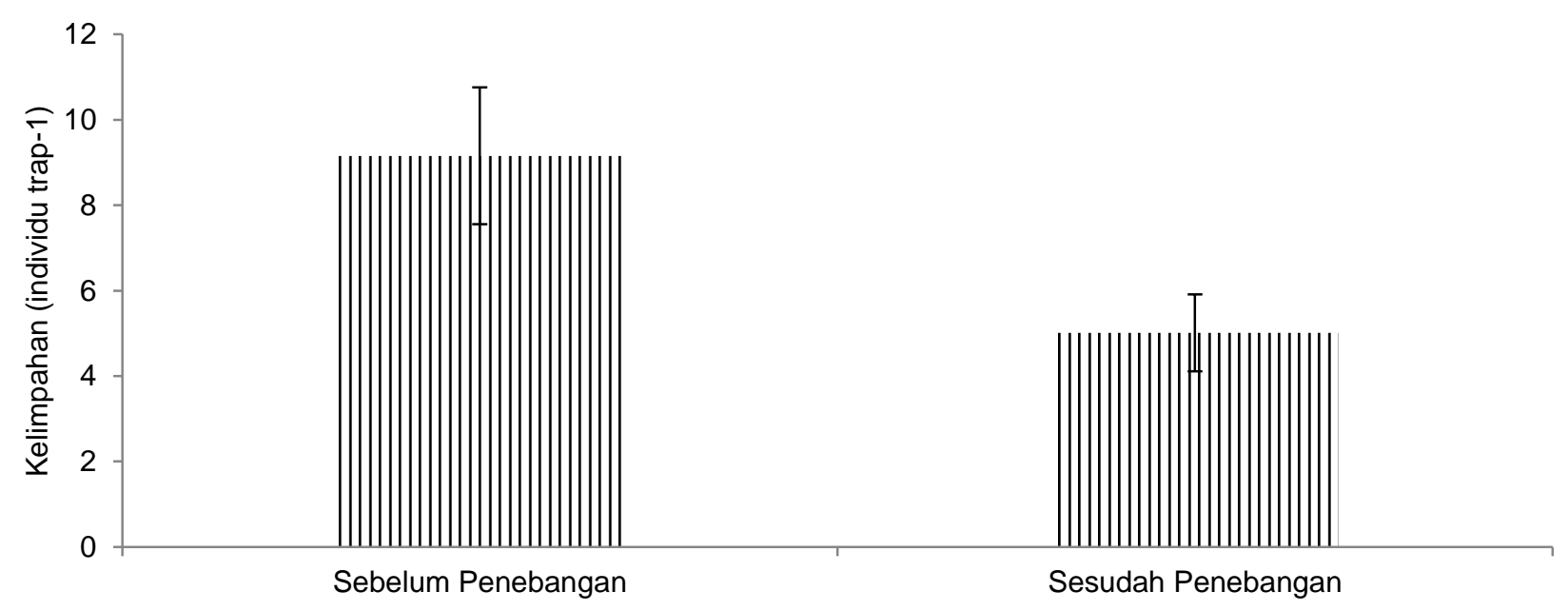

Gambar 1 Rataan kelimpahan semut tanah sebelum dan sesudah penebangan pohon.

Tabel 1 Hasil uji $t$ dua sampel berpasangan kelimpahan semut tanah sebelum dan sesudah penebangan (ind/trap)

\begin{tabular}{lrrrrrrr}
\hline \multicolumn{1}{c}{ Perlakuan } & $N$ & Rataan & $\begin{array}{c}\text { Standar } \\
\text { deviasi }\end{array}$ & $\begin{array}{c}\text { Kesalahan } \\
\text { contoh rataan }\end{array}$ & $T$-hit & $T$-tab & $P$ \\
\hline $\begin{array}{l}\text { Sebelum } \\
\text { penebangan }\end{array}$ & 135 & 9,20 & 18,40 & 1,60 & 2,27 & 1,96 & 0,024 \\
$\begin{array}{l}\text { Sesudah } \\
\text { penebangan }\end{array}$ & 135 & 5,00 & 10,50 & 0,90 & & & \\
\hline
\end{tabular}


Tabel 2 Kelimpahan morfospesies semut tanah sebelum dan sesudah penebangan di lokasi penelitian

\begin{tabular}{|c|c|c|c|c|c|}
\hline \multirow[b]{2}{*}{ Subfamili } & \multirow[b]{2}{*}{ Morfospesies } & \multicolumn{2}{|c|}{ Sebelum penebangan } & \multicolumn{2}{|c|}{ Sesudah 0enebangan } \\
\hline & & $\begin{array}{l}\text { Kelimpahan } \\
\text { (Individu) }\end{array}$ & $\begin{array}{c}\text { Persentase } \\
(\%)\end{array}$ & $\begin{array}{l}\text { Kelimpahan } \\
\text { (Individu) }\end{array}$ & $\begin{array}{c}\text { Persentase } \\
(\%)\end{array}$ \\
\hline Ponerinae & Cryptopone sp. & 762 & 61.65 & 260 & 38.40 \\
\hline Ponerinae & Odontoponera sp. & 138 & 11.17 & 113 & 16.69 \\
\hline Myrmicinae & Lophomyrmex sp. & 127 & 10.28 & 188 & 27.77 \\
\hline Ponerinae & Diacamma sp. & 59 & 4.77 & 30 & 4.43 \\
\hline Myrmicinae & Mesostruma sp. & 37 & 2.99 & 10 & 1.48 \\
\hline Dolichoderinae & Leptomyrmex sp. & 31 & 2.51 & 2 & 0.30 \\
\hline Formicinae & Oecophylla sp. & 13 & 1.05 & 20 & 2.95 \\
\hline Myrmicinae & Vombisidris sp. & 13 & 1.05 & 5 & 0.74 \\
\hline Formicinae & Camponotus sp. & 12 & 0.97 & 12 & 1.77 \\
\hline Ponerinae & Myopias sp. & 8 & 0.65 & 1 & 0.15 \\
\hline Formicinae & Euprenolepis sp. & 6 & 0.49 & 1 & 0.15 \\
\hline Dolichoderinae & Iridomyrmex sp. & 6 & 0.49 & 7 & 1.03 \\
\hline Myrmicinae & Monomorium sp. & 6 & 0.49 & 11 & 1.62 \\
\hline Formicinae & Paraparatrecina sp. & 3 & 0.24 & 2 & 0.30 \\
\hline Formicinae & Calomyrmex sp. & 2 & 0.16 & 4 & 0.59 \\
\hline Formicinae & Dendromyrmex sp. & 2 & 0.16 & 2 & 0.30 \\
\hline Myrmicinae & Recurvidris sp. & 1 & 0.08 & 2 & 0.30 \\
\hline Formicinae & Lasiophanes sp. & 1 & 0.08 & 1 & 0.15 \\
\hline Ponerinae & Harpegnathos sp. & 2 & 0.16 & 0 & 0.00 \\
\hline Myrmicinae & Pheidologeton sp. & 2 & 0.16 & 0 & 0.00 \\
\hline Ponerinae & Anochetus sp. & 1 & 0.08 & 0 & 0.00 \\
\hline Myrmicinae & Chimaeridris sp. & 1 & 0.08 & 0 & 0.00 \\
\hline Myrmicinae & Crematogaster sp. & 1 & 0.08 & 0 & 0.00 \\
\hline Formicinae & Prenolepis sp. & 1 & 0.08 & 0 & 0.00 \\
\hline Ponerinae & Psalidomyrmex sp. & 1 & 0.08 & 0 & 0.00 \\
\hline Myrmicinae & Rhoptromyrmex sp. & 0 & 0.00 & 2 & 0.30 \\
\hline Ponerinae & Lalomyrmex sp. & 0 & 0.00 & 1 & 0.15 \\
\hline Ponerinae & Gnamptogenys sp. & 0 & 0.00 & 1 & 0.15 \\
\hline Ponerinae & Heteroponera sp. & 0 & 0.00 & 1 & 0.15 \\
\hline \multirow[t]{2}{*}{ Dolichoderinae } & Technomyrmex sp. & 0 & 0.00 & 1 & 0.15 \\
\hline & Jumlah & 1236 & 100 & 677 & 100 \\
\hline
\end{tabular}

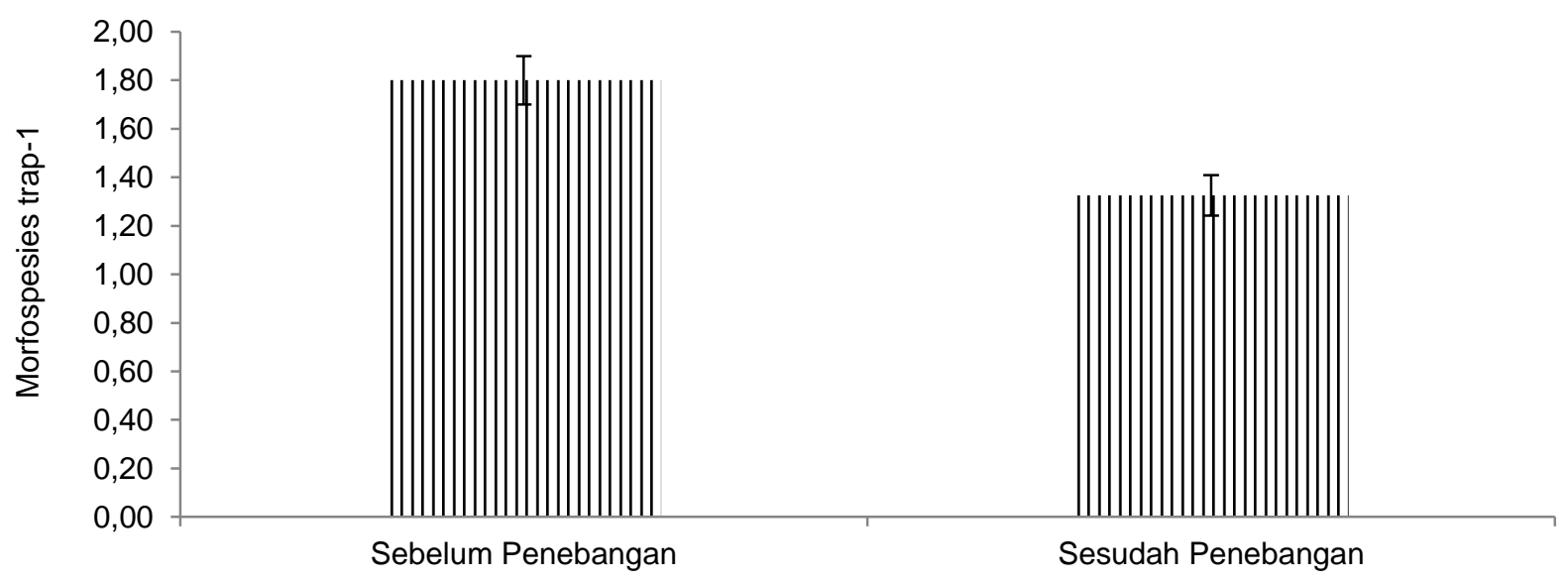

Gambar 2 Rata-rata jumlah morfospesies semut tanah sebelum dan sesudah penebangan.

penebangan, sementara untuk pencari makan bertambah. Jumlah pemangsa, pemakan bangkai, dan penyebar biji sesudah penebangan berturut-turut adalah $64,4 \%, 0,30 \%$, dan $0,15 \%$, sedangkan pencari makan bertambah menjadi 35,2\% (Gambar 4).

Rata-rata suhu udara sebelum penebangan pohon adalah $31,6^{\circ} \mathrm{C}$ dan setelah penebangan pohon meningkat menjadi $32,6^{\circ} \mathrm{C}$. Rata-rata kelembapan udara sebelum penebangan $79 \%$, sedangkan setelah penebangan menurun menjadi $76 \%$. Rata-rata tutupan tajuk menurun sebesar $23 \%$ setelah penebangan dan tebal serasah meningkat $0,6 \mathrm{~cm}$ setelah penebangan pohon (Tabel 4). Hubungan antara kelimpahan semut dengan suhu bernilai negatif. Hubungan antara kelimpahan semut dengan kelembapan udara, tutupan tajuk, dan tebal serasah bernilai positif. Kelimpahan semut hymenoptera tidak berkorelasi signifikan dengan faktor lingkungan $(p<0,05)$ (Tabel 5).

Penebangan pohon dengan sistem tebang pilih pada pengusahaan hutan produksi alam sekunder 
Tabel 3 Uji t dua sampel berpasangan komposisi morfospesies semut tanah sebelum dan sesudah penebanga

\begin{tabular}{cccccccc}
\hline Perlakuan & $\begin{array}{c}\text { Jumlah } \\
\text { contoh }\end{array}$ & Rataan & $\begin{array}{c}\text { Simpangan } \\
\text { baku }\end{array}$ & $\begin{array}{c}\text { Kesalahan contoh } \\
\text { rataan }\end{array}$ & $T$-hit & $T$-tab & $P$ \\
\hline Sebelum penebangan & 135 & 1,80 & 1,16 & 0,10 & 3,65 & 1,96 & 0,000 \\
Sesudah penebangan & 135 & 1,33 & 0,97 & 0,83 & & & \\
\hline
\end{tabular}

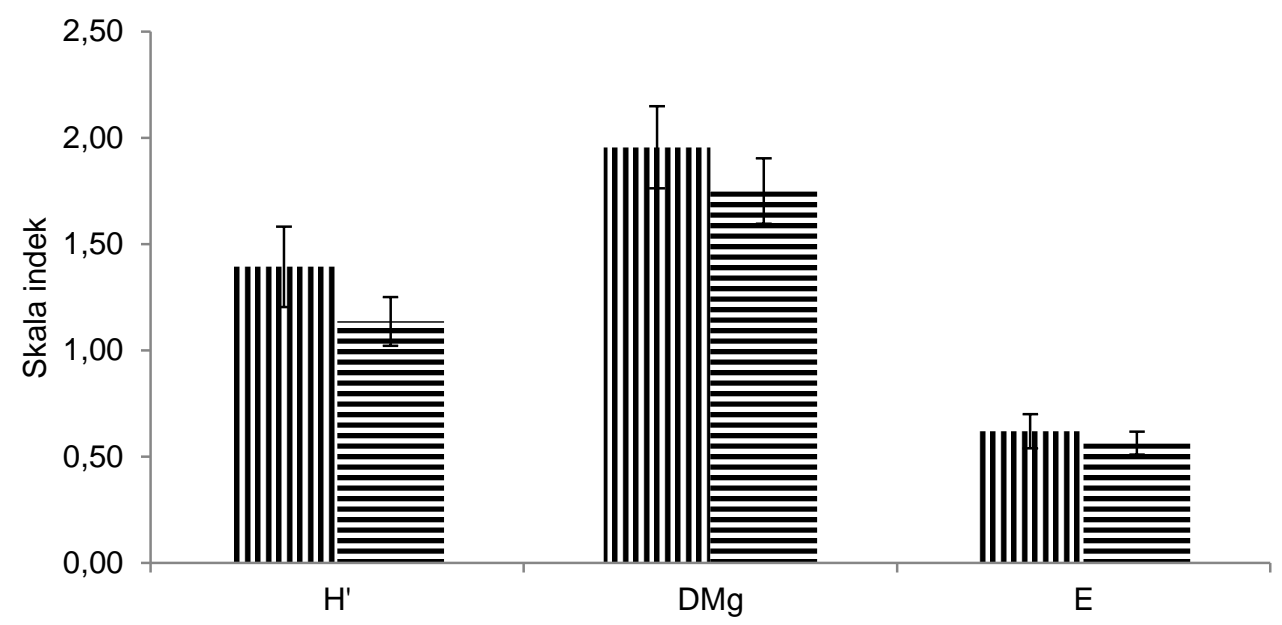

Gambar 3 Index keanekaragaman (H'), indek kekayaan (DMg) dan indek kemerataan jenis (E) semut tanah sebelum dan sesudah penebangan.

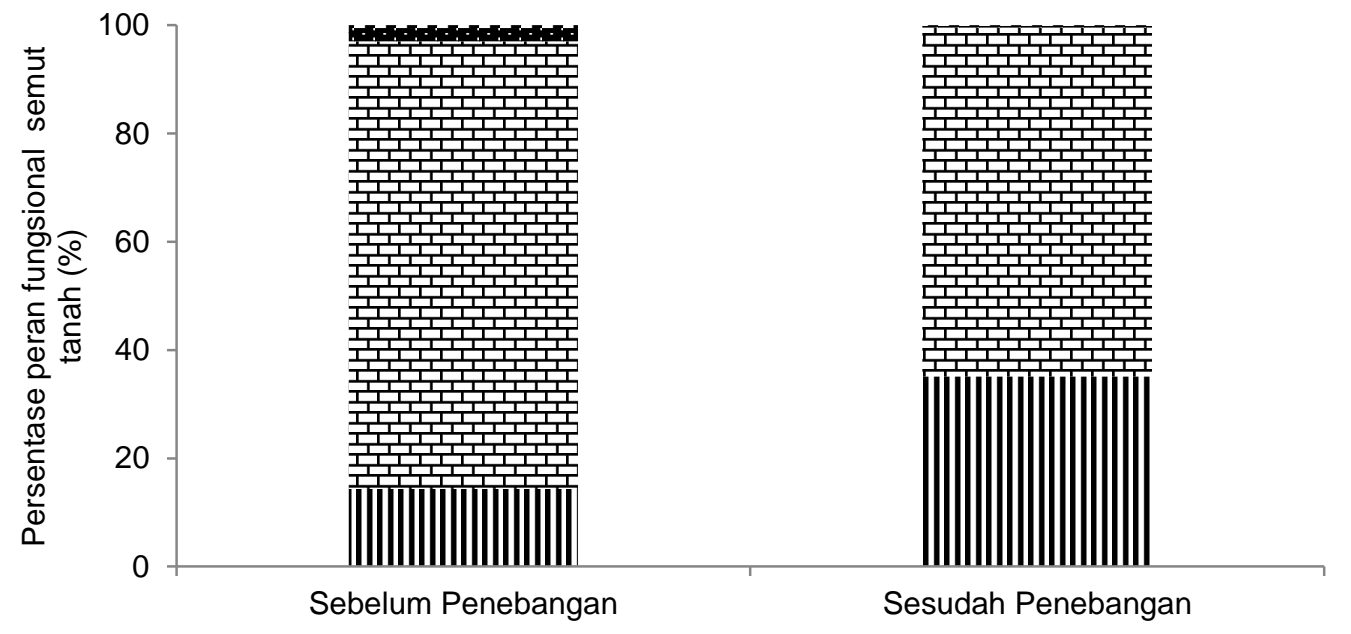

\author{
- Penyebar biji \\ a Pemakan bangkai \\ × Pemangsa \\ II Pencari makan
}

= Sesudah Penebangan

Gambar 4 Peran fungsional semut tanah sebelum dan sesudah penebangan di lokasi penelitian.

berpengaruh nyatapada kelimpahan dan jumlah morfospesies semut tanah. Kelimpahan semut sesudah penebangan pohon menurun 45\%, sementara jumlah morfospesies sesudah penebangan berkurang $26 \%$. Tebang pilih menyebabkan tutupan tajuk hutan berkurang dan menciptakan celah tebangan (felling gaps) dan perubahan iklim mikro di lantai hutan. Kondisi ini memberi jalan sinar matahari masuk sampai ke lantai hutan sehingga lantai hutan menjadi lebih hangat dibandingkan sebelum penebangan (Kendrick et al. 2015.). Perubahan iklim mikro akibat penebangan pohon memengaruhi kelimpahan semut tanah secara signifikan dalam rentang waktu yang singkat. Hasil uji $t$ berpasangan menunjukkan bahwa kelimpahan semut sebelum penebangan dan setelah penebangan berbeda nyata $(p<0,05)$. Temuan ini sejalan dengan hasil penelitian sebelumnya. Mangels et al. (2015) menemukan bahwa pemanenan hutan menyebabkan penurunan kelimpahan serangga pemakan tanaman (herbivor) pada tegakan Fagus sylvatica. Sementara Vasconcelos et al. (2000) menyatakan bahwa penebangan hutan sebesar 8 pohon/ha di hutan tropis Amazon menurunkan jumlah spesies semut. Kelimpahan semut tanah setelah penebangan menurun 45\%. Hasil penelitian ini lebih besar dibandingkan penelitian sebelumnya yang melaporkan bahwa pemanenan hutan menurunkan kelimpahan semut hingga 30\% (Woodcock et al. 2013)

Indeks keanekaragaman, kekayaan, dan kemerataan jenis semut tanah menurun setelah kegiatan penebangan. Jumlah spesies per plot yang tercatat sesudah penebangan cenderung lebih sedikit dibandingkan sebelum penebangan, tetapi 
Tabel 4 Rata-rata suhu udara, kelembapan udara, tutupan tajuk, dan tebal serasah sebelum dan sesudah penebangan pohon

\begin{tabular}{lcc}
\hline Faktor Lingkungan & Sebelum Penebangan & Setelah Penebangan \\
\hline Suhu ( $\left.{ }^{\circ} \mathrm{C}\right)$ & $31,6 \pm 0,88$ & $32,6 \pm 0,98$ \\
Kelembaban udara (\%) & $79,0 \pm 6,50$ & $76,0 \pm 6,60$ \\
Tutupan tajuk (\%) & $83,3 \pm 4,44$ & $59,4 \pm 8,03$ \\
Tebal serasah (cm) & $3,22 \pm 0,31$ & $3,71 \pm 0,46$ \\
\hline
\end{tabular}

Tabel 5 Uji korelasi Pearson antara kelimpahan semut tanah dengan suhu, kelembaban udara, tutupan tajuk, dan tebal serasah (korelasi Pearson/probabilitas)

\begin{tabular}{|c|c|c|c|c|c|}
\hline & Kelimpahan & Suhu & $\begin{array}{c}\text { Kelembapan } \\
\text { udara }\end{array}$ & Tutupan tajuk & Tebal serasah \\
\hline Kelimpahan & - & & & & \\
\hline Suhu & $-0,065 / 0,287$ & - & & & \\
\hline Kelembapan udara & $-0,023 / 0,711$ & $-0,730 / 0,000$ & - & & \\
\hline Tutupan tajuk & $0,139 / 0,022$ & $-0,442 / 0,000$ & $0,072 / 0,239$ & - & \\
\hline Tebal serasah & $-0,232 / 0,000$ & $0,233 / 0,000$ & $0,016 / 0,794$ & $-0,592 / 0,000$ & - \\
\hline
\end{tabular}

perbedaannya tidak signifikan. Hasil penelitian ini sejalan dengan hasil penelitian Kalif et al. (2001), bahwa pemanenan hutan mendorong pergeseran komposisi spesies semut tanpa mengubah kekayaan jenisnya. Lebih lanjut Vanconcelos et al. (2000) memaparkan bahwa ragam kekayaan dan kemerataan jenis, serta rataan kelimpahan semut per plot tidak terlalu besar antara hutan yang ditebang dan hutan yang tidak ditebang. Sebagian besar spesies semut yang ditemukan di plot hutan yang tidak ditebang juga ditemukan di plot hutan yang ditebang. Hal ini dapat terjadi kemungkinan karena jarak waktu pengamatan yang pendek antara sebelum dan sesudah penebangan. Kepadatan populasi sebagian besar jenis semut berubah akibat penebangan hutan. Dunn (2004) melaporkan bahwa pemanenan hutan mengakibatkan dampak yang kecil terhadap kekayaan jenis semut.

Hasil penelitian menunjukkan bahwa tebang pilih tidak hanya meningkatkan kelimpahan beberapa morfospesies semut tanah, tetapi juga menurunkan kelimpahan beberapa morfospesiesnya. Sebagian besar kelompok yang meningkat kelimpahannya sesudah penebangan di lokasi penelitian adalah pemakan (forager) dan pemakan segala (grounddwelling omnivore), sedangkan kelompok semut tanah yang menurun kelimpahannya sesudah penebangan adalah pemangsa di tanah (ground-dwelling predator), kemudian diikuti pemakan bangkai dan penyebar biji. Penurunan kelimpahan kelompok pemangsa sebesar $18,3 \%$, pemakan bangkai $2,2 \%$ dan penyebar biji $0,34 \%$. Penelitian ini sejalan dengan penelitian GarciaMartinez et al. (2015), bahwa kelimpahan pemangsa di tanah di hutan yang terganggu lebih rendah dibandingkan hutan yang tidak terganggu, sedangkan kelimpahan pemakan segala di hutan terganggu lebih tinggi dibandingkan di hutan yang tidak terganggu. Morfospesies yang menurun kelimpahannya sesudah penebangan adalah Cryptopone sp., Odontoponera sp., Diacamma sp., Mesostruma sp., Leptomyrmex sp., Vombisidris sp., Myopias sp., Euprenolepis sp., dan Paratrecina sp. Penurunan kelimpahan kelompok semut ini sesudah penebangan diperkirakan karena berkurangnya vegetasi hutan sebagai sumber makanan dan tempat bersarang bagi kelompok semut ini. Schonberg et al. (2004) menggambarkan bahwa kompleksitas struktur vegetasi hutan memengaruhi kekayaan jenis semut. Semakin kompleks struktur vegetasi hutan, semakin banyak banyak kesesuaian mikro habitat untuk kelompok semut yang berbeda, terutama jika terdapat pohon yang besar. Hasil penelitian ini sejalan dengan hasil penelitian sebelumnya, bahwa kelimpahan semut pemangsa di tanah di hutan yang terganggu lebih kecil dibandingkan di hutan yang tidak terganggu, sementara kelimpahan pemakan segala di tanah di hutan terganggu lebih tinggi dibandingkan hutan yang tidak terganggu (Watt et al. 2015).

Hasil penelitian ini mengungkap bahwa subfamili Ponerinae (Cryptopone sp., Odontoponera sp.) merupakan subfamili semut tanah yang terbanyak di lokasi penelitian, baik sebelum maupun setelah penebangan pohon. Hasil penelitian ini juga didukung oleh temuan Haneda et al. (2005), bahwa spesies yang termasuk dalam subfamili Ponerinae sebagian besar dapat ditemukan di semua habitat hutan dan lebih aktif keluar untuk mencari makan dibandingkan dengan subfamili lain. Subfamili semut ketiga terbesar di lokasi penelitian adalah Myrmicinae (Lophomyrmex sp.). Subfamili ini meningkat $48 \%$ sesudah penebangan. Morfopsesies lain dari subfamili Myrmicinae yang meningkat setelah penebangan adalah Monomorium sp. dan Recurvidris sp. Subfamili lainnya yang meningkat sesudah penebangan adalah Dolichoderinae (Iridomyrmex sp.) dan Formicinae (Oecophylla sp. dan Calomyrmex sp.). Dua subfamili ini diperkirakan menyukai daerah terbuka akibat berkurangnya tutupan tajuk akibat tebang pilih. Berdasarkan temuan Andersen (1995), Dolichoderine adalah spesies habitat terbuka, sangat aktif dan agresif, serta menggunakan pengaruh persaingan utama terhadap semut-semut lainnya. Sementara itu, King et al. (2019) melaporkan bahwa Dolichoderine yang dominan secara perilaku jarang atau tidak ditemukan di hutan yang tidak terganggu. Semut yang umum ditemukan di hutan yang terganggu adalah kelompok generalis dari subfamili Myrmicine dan oportunis. Gangguan habitat lebih disukai oleh kelompok oportunis, dan karena gangguan tersebut 
melibatkan pembukaan kanopi, hal ini menyebabkan kolonisasi oleh Iridomyrmex sp. dan Dolichoderine yang dominan. Watt et al. (2002) menambahkan bahwa meningkatnya beberapa morfospesies semut tersebut setelah penebangan hutan diperkirakan karena persediaan daun dan ranting yang banyak sebagai sumber makanan setelah penebangan. Penebangan hutan meningkatkan gangguan habitat dan sumber daya makanan, serta memungkinkan bagi kelompok semut spesialis yang menyukai gangguan hutan untuk muncul.

Tebang pilih pada pengusahaan hutan alam sekunder meningkatkan tebal serasah dan menurunkan persentase tutupan tajuk. Kelimpahan semut tanah berhubungan erat dengan tutupan tajuk dan tebal serasah (Savitha et al. 2008). Kelimpahan serasah merupakan indikasi keberadaan semut-semut tanah yang dominan dari subfamili Ponerinae. Subfamili ini kebanyakan adalah semut yang tinggal di tanah yang bersarang dan mencari makan secara eksklusif di dalam tanah dan serasah hutan (Andersen 1995; Fernandes et al. 2019).

\section{KESIMPULAN}

Dari kajian ini disimpulkan bahwa tebang pilih di hutan produksi alam sekunder berpengaruh nyata pada kelimpahan dan komposisi morfospesies semut tanah dalam jangka pendek. Kelimpahan dan komposisi morfospesies semut tanah setelah penebangan pohon lebih rendah dibandingkan sebelum penebangan pohon. Indeks keanekaragaman, indeks kekayaan, dan indeks kemerataan jenis semut tanah sebelum penebangan mirip dengan keadaan sesudah penebangan. Kelimpahan semut tanah berkorelasi nyata dengan tutupan tajuk dan tebal serasah hutan.

\section{UCAPAN TERIMA KASIH}

Penelitian lapangan ini tidak akan dapat diselesaikan tanpa dukungan PT Ratah Timber yang telah menyediakan data sekunder, fasilitas transportasi, akomodasi, dan tenaga pembantu lapangan.

\section{DAFTAR PUSTAKA}

Abbott I, Burbidge T, Strehlow K, Mellican A, Wills A. 2002. Logging and burning impacts on cockroaches, crickets and grasshoppers and spiders in Jarrah Forest, Western Australia. Forest Ecology and Management 174: 383-399.

Andersen AN. 1995. A classification of Australia ant communities based on functional groups which parallel plant life-forms in realtion to stress and disturbance. Journal of Biogeography. 22: 15-29.
Bihn JH, Verhaagh M, Brande M, Roland B. 2008. Do secondary forest act as refuges for old growth forest animals? Recovery of ant diversity in the Atlantic forest of Brazil. Biological Conservation. 141: 733-743.

Bolton B. 1994. Identification guide to the ant genera of the world. London (GB): Harvard Univ Press.

Burivalova Z, Seherciaglu CH, Koh LP. 2014. Treshold of logging intensity to maintain tropical forest biodiversity. Conservation Biology. 24: 1893-1898.

Chaudary A, Burivalova Z, Koh LP, Hellweg S. 2016. The impact of forest management on species richness: Global Meta-Analysis and economic Trade-off. www.nature.com/scientific report/DOI: 10.1038.sRep23954.

Dunn RR. 2004. Managing the tropical landscape: A comparison of the effect of logging and forest convertion to agriculture on ants, birds, and lepidoptera. Forest Ecology and Management. 199: 215-224.

Fernandes TT, Silva RR, de Sauza-Compona DR, da Silva OGM, de Cartro Marini MS. 2019. Winged ants (Hymenoptera: Formicidae) presence in twigs on the leaf litter of the Atlantic forest. Biota Neotropica. 19: e29180694.

Garcia-Martinez MA, Martinez-Tlapa DLM, PerezToledo GR, Quiroz-Robledo LN, Castano-Meneses G, Laborde J, Valenzuela-Gonzalez JE. 2015. Taxonomic, species and functional group diversity of ants in a tropical anthropogenic landscape. Tropical Conservation Science. 8: 1017-1032.

Gaveau DLA, Kshatriya M, Shell D, Siloan S, Molidena E. Wijaya A, Wich S, Acrenaz M, Hansen M, Broich M, Guariguata MR, Pacheco P, Polapov P, Turubanova S, Meijaard E. 2013. Reconciling forest conservation and logging in Indonesia Borneo. PLOS ONE. 8(8): e69887. http:/doi.org/10.1371/journal.pone.0069887.

Gibson L, Lee TM, Koh LP, Brook BW, Gardner TA, Barlow J, Peres CA, Bradshaw CJA, Laurance WF, Lovejoy TE, SOdhi NS. 2011. Primary forests are irreplaceable for sustaining tropical diversity. Nature. 478: 378-383.

Griffiths HM, Ashton LA, Walker AE, Hason F, Evans TA, Eggleton P, Parr CL, 2017. Nats are the major agents of resources removal from tropical rainforests. Journal of Animal Ecology. 87(1): 293-300. https://doi.org/10.1111/13652656.12728.

Haneda NF, Sajap AS, Hussin MZ. 2005. A study of two ant (Hymenoptera: Formicidae) sampling methods in tropical rain forest. Journal of Applied Science. 5(10): 1732-1734.

Hawthorne WD, Marshall CM, Juam MA, Agyeman VK. 2011. The impact of logging damage on tropical Rainforests, their recovery and regenaration. An 
annotated Bibliography. Oxford (GB): Oxford Forestry Institute.

Hosoishi S, Hashimoto Y, Park S-H, Yamane S, Ogata K. 2017. A comparison of ground dwelling and arboreal ant assemblages (Hymenoptera: Formicidae) in lowland forest of Cambodia. Raffles Buletin of Zoology. 65: 416-425.

Hoffman BD, Andersen AN. 2003. Responses of ants to disturbance in Australia, with particular reference to functional groups. Australian Ecology. 28: 444-464.

Kalif KAB, Azevedo-Ramos C, Montenho P, Malcher SAO. 2001. The effect of logging on thr groundforaging ant community in Eastern Amazonia. Studies on Neotropical and Environment. 36: 215-219.

Kendrick JA, Ribbons RR, Classen AT, Ellison AM. 2015. Changes in canopy structure and ant assembalges affect soil ecosystem variables as a foundation species declines. Ecospere 6: 77. http://dx.doi.org/10.1890/ES14-00447.1.

King JR, Andersen AN, Cutter AD. 2019. Ants as bioindictors of habitat disturbance: Validation of the functional group model for Australias humid tropics. Biological Conservation. 7: 1627-1638.

Klimes P. 2017. Diversity and specificity of ant-plant interactions in canopy communities: insights from primary and secondary tropical forest in New Guinea. In Oliveira PS, Kopter S. (Eds): Ant-plant interactions: Impact of humans on terrestrial ecosystem. Cambridge (GB): Cambridge university press.

Lange M, Turke M, Pasalic E, Boch S, Hessenmuller D, Muller J, Prati D, Socher SA, Fischer M, Weisser WW, Gossner MM. 2014. Effects of forest management on ground dwelling beetles (Coleoptera, Carabidae, Staphylinidae) in Central Europe are mainly mediated by changes in forest structure. Forest Ecology and Management. 329: 166-176.

Latumahina F, Musyafa, Sumardi, Putra NS. 2015 Respon semut terhadap kerusakan anthropogenic di Hutan Sirimau, Ambon. Jurnal Manusia dan Lingkungan. 22: 169-178.

Lavelle P, Decaens T, Aubert M, Barot S, Blouin M, Bureau F, Margerie P, Mora P, Rossi J-P. 2006. Soil invertrebates and ecosystem services. European Journal of Soil Biology. 42: S3-S15.

Mangel J, Bluthigen N, Frank K, Grassein F, Hilpert A, Moody K. 2015. Tree species composition and harvest intensity affect herbivore density and leaf damage on beech, Fagus sylvatica, in different landscape context. PLOS ONE. 10(5): e0126140. http:/doi.org/10.1371/journal.pone.0126140.

Mathieu J, Rossi J-P, Moid P, Lavelle P, Martin PF, Da S, Rouland C, Gremaldi M.. 2005. Recovery of soil macrofauna communities after forest clearance in eastern Amazonia, Brazil. Conservation Biology. 19: 1598-1605.

Negro M, Vacchiano G, Berreti R, Chamberlain DE, Palestrini C, Motta R, Rolando A. 2014. Effects of forest management on ground beetle diversity in alpine beech (Fagus sylvatica) stands. Forest Ecology and Management. 328: 300-309.

Savitha S, Barve N, Davidar P. 2008. Response of ants to disturbance gradients in and around Bangalore, India. Tropical Ecology. 49: 235-243.

Schreven SJJ. 2013. Ant community composition in relation to forest disturbance in a Bornean tropical peat swamp forest. [Thesis]. Wageningen (ND): Wageningen University.

Schonberg LA, Longino JT, Nadkarni NM, Yanoviak SP, Gering JC. 2004. Arboreal Ant Species Richness in Primary Forest, Secondary Forest, and Pasture Habitats of a Tropical Montane Landscape. Biotropica. 36: 402-409.

Strehlow K, Bradley JS, Davis J, Friend GR. 2002. Short term impacts of logging on invertebrate communities in jarrah forests in south-west Western Australia. Forest Ecology and Management 162: 165-184.

Vasconcelos HI, Vilhena JMS, Caliri GJA. 2000. Responses of ants to selective logging of a central Amazonian forest. Journal of Applied Ecology. 37: 508-514.

Watt AD, Stork NE, Bolto B. 2002. The diversity and abundance of ants in relation to forest disturbance and plantation establishment in southern Cameroon. Journal of Applied Ecology. 39: 18-30.

Woodcock P, Edward DP, Newton RJ, Vun Khen C, Bottrell SH, Hamer KC. 2013. Impacts of intensive logging on the trophic organisation of and communities in a biodiversity hotspot. PLOS ONE. 8(4):e60756.

Yeo K, Konate S, Tiho S, Camara SK. 2011. Impacts of land use types on ant communities in a tropical forest margin (Oume-d'lvore). African Journal of Agricultural Research. 6: 260-274. 